UNITED STATES DEPARTMENT OF THE INTERIOR GEOLOGICAL SURVEY

TEXT TO ACCOMPANY:

COAL RESOURCE OCCURRENCE

AND

COAL DEVELOPMENT POTENTIAL

MAPS

OF THE

HYLTON RANCH QUADRANGLE, CONVERSE COUNTY, WYOMING

BY

INTRASEARCH INC.

DENVER， COLORADO

OPEN FILE REPORT 79-471

1979

This report is preliminary, and has not been edited or reviewed for conformity with United States Geological Survey standards or stratigraphic nomenclature. 
PAGE

I. INTRODUCTION 1

II. GEOLOGY 3

III. DATA SOURCES $\quad 7$

IV. COAL BED OCCURRENCE 9

Figure 1.--Isopach and Mining Ratio Map of 11 Anderson Coal Bed in Hylton Ranch Quadrangle, Converse County, wyoming.

Figure 2.--Structure Contour and Isopach of Overburden Map of Anderson Coal Bed in Hylton Ranch Quadrangle, Converse County, Wyoming.

Figure 3.--Areal Distribution of Identified Resources Map of Anderson Coal Bed in Hylton Ranch Quadrangle, Converse County, Wyoming.

Figure 4.--Coal Development Potential for Surface Mining Methods Map, Hylton Ranch Quadrangle, Converse County, Wyoming.

V. GEOLOGICAL AND ENGINEERING MAPPING PARAMETERS

VI. COAL DEVELOPMENT POTENTIAL

Table 1.--Strippable Coal Reserve Base Data (in short tons) for Federal Coal Lands in the Hylton Ranch Quadrangle, Converse County, Wyoming. 
TABLE OF CONTENTS (continued)

MAPS

1. Coal Data Map

2. Boundary and Coal Data Map

3. Coal Data Sheet
PLATES

1

2

3

I 
CONVERSION TABLE

\section{TO CONVERT}

inches

feet

miles

acres

tons (short)

cubic yards/ton

acre feet

Btu/lb

Btu/1b

Fahrenheit
MULTIPLY BY

2.54

0.3048

1.609

0.40469

0.9072

0.8428

0.12335

2.326

0.55556

$5 / 9(\mathrm{~F}-32)$
TO OBTAIN

centimeters (cm)

meters (m)

kilometers $(\mathrm{km})$

hectares (ha)

metric tons (t)

cubic meters per metric tons

hectare-meters

kilojoules/kilogram $(\mathrm{kJ} / \mathrm{kg})$

kilocalories/kilogram ( $\mathrm{kcal} / \mathrm{kg}$ )

Celsius 
I. Introduction

This report and accompanying maps set forth the Coal Resource Occurrence (CRO) and Coal Development Potential (CDP) of coal beds within the Hylton Ranch Quadrangle, Converse County, Wyoming. This CRO and CDP map series (U. S. Geological Survey Open-File Report 79-471) includes 3 plates. The project is compiled by IntraSearch Inc., 1600 Ogden Street, Denver, Colorado, under KRCRA Eastern Powder River Basin, Wyoming Contract Number 14-08-0001-17180. This contract is a part of a program to provide an inventory of unleased federal coal in Known Recoverable Coal Areas (KRCRAs) in the western United States.

The Hylton Ranch Quadrangle is located in Converse County, in northeastern Wyoming. It encompasses parts of Townships 34 and 35 North, Ranges 74 and 75 West, and covers the area: $42^{\circ} 52^{\prime} 30^{\prime}$ to $43^{\circ} 00^{\prime}$ north latitude; $105^{\circ} 45^{\prime}$ to $105^{\circ} 52^{\prime} 30^{\prime \prime}$ west longitude.

Main access to the Hylton Ranch Quadrangle is provided by the Glenrock-Ross Road, which angles northeastward across the southern half of the quadrangle, and by another light-duty road, which branches off from the Glenrock-Ross Road and extends northward along the western boundary of the quadrangle. The closest railroad is the Chicago Burlington trackage approximately 3 miles $(5 \mathrm{~km})$ to the south near Glenrock, Wyoming.

Sand Creek, a tributary of the Platte River, flows southeastward across the Hylton Ranch Quadrangle. Topographic elevations within the quadrangle vary from less than 5020 feet $(1530 \mathrm{~m})$ above sea level in the southwestern corner to more than 5880 feet $(1792 \mathrm{~m})$ above sea level in the northeastern quadrant.

The 10 to 12 inches (25 to $30 \mathrm{~cm}$ ) of annual precipitation that falls in this semi-arid region accrues principally in the springtime. Summer and fall precipitation usually originates from thunderstorms, and infrequent snowfalls of six inches $(15 \mathrm{~cm})$ or less generally characterize 
winter precipitation. Although temperatures ranging from less than $-25^{\circ} \mathrm{F}$ $\left(-32^{\circ} \mathrm{C}\right)$ to more than $100^{\circ} \mathrm{F}\left(38^{\circ} \mathrm{C}\right)$ have been recorded near Douglas, Wyoming, average wintertime minimums and summertime maximums approach $+5^{\circ}$ to $+15^{\circ} \mathrm{F}\left(-15^{\circ}\right.$ and $\left.-9^{\circ} \mathrm{C}\right)$ and $75^{\circ}$ to $90^{\circ} \mathrm{F}\left(24^{\circ}\right.$ to $\left.32^{\circ} \mathrm{C}\right)$, respectively. Surface ownership is divided among fee, state, and federal categories. State and federal lands are generally leased to ranchers for grazing purposes. Details of surface ownership are available at the Converse County Courthouse in Douglas, Wyoming. Details of mineral ownership on federal lands are available from the U. S. Bureau of Land Management in Cheyenne, Wyoming. Federal coal ownership is shown on Plate 2 of the Coal Resource Occurrence maps. The non-federal coal belongs to both fee and state owners.

The Coal Resource Occurrence and Coal Development Potential program is restricted to unleased federal coal and focuses upon: 1) the delineation of lignite, subbituminous coal, bituminous coal, and anthracite at the surface and in the subsurface on federal land; 2) subdivision of deposits into measured, indicated, and inferred reserve resource categories, and hypothetical resources; 3) the measurement of coal resources in place as well as recoverable reserves; and 4) the determination of the potential for surface or underground mining, and in-situ gasification of the coal beds. This report contains an evaluation of the coal resources of all unleased federal coal beds in the quadrangle, which are 5 feet $(1.5 \mathrm{~m})$ or greater in thickness and occur at depths down to 3000 feet $(914 \mathrm{~m})$. No resources or reserves are computed for leased federal coal, state coal, fee coal, or lands encompassed by coal prospecting permits and preference-right lease applications. 
Surface and subsurface geological and engineering extrapolations drawn from the current data base suggest the occurrence of approximately 19 million tons ( 17 million metric tons) of unleased federal coal resources in the Hylton Ranch Quadrangle. The suite of maps that accompany this report portray the coal resource and reserve occurrence in detail. For the most part, this report supplements the cartographic information, with minimum duplication of the map data.

II. Geology

Regional. The thick, economic coal deposits of the Powder River Basin in northeastern Wyoming occur mostly in the Tongue River Member of the Fort Union Formation, and in the lower part of the Wasatch Formation. Approximately 3000 feet $(914 \mathrm{~m})$ of the Fort Union Formation, that includes the Tongue River, Lebo, and Tullock Members of Paleocene age, are unconformably overlain by approximately 700 feet $(213 \mathrm{~m})$ of the Wasatch Formation of Eocene age. These Tertiary formations lie in a structural basin flanked on the east by the Black Hills uplift, on the south by the Hartville and Casper Mountain uplifts, and on the west by the Casper Arch and the Big Horn Mountain uplift. The structural configuration of the Powder River Basin originated in Late Cretaceous time, with episodic uplift thereafter. The Cretaceous Cordillera was the dominant positive land form throughout the Rocky Mountain area at the close of Mesozoic time.

Outcrops of the Wasatch Formation and the Tongue River Member of the Fort Union Formation cover most of the areas of major coal resource occurrence in the Powder River Basin. The Tongue River Member is composed of very fine-grained sandstones, siltstones, claystones, shales, carbonaceous shales, and numerous coal beds. The Lebo Shale Member of 
the Fort Union Formation consists of light-to dark-gray very finegrained to conglomeratic sandstone with interbedded siltstone, claystone, carbonaceous shale and thin coal beds. Thin bedded calcareous ironstone concretions interbedded with massive white sandstone and slightly bentonitic shale occur throughout the unit.

The Lebo Member is mapped at the surface northeast of Recluse, Wyoming, east of the principal coal outcrops and associated clinkers (McKay, 1974), and presumably projects into the subsurface beneath much of the basin. One of the principal characteristics for separating the Lebo and Tullock Members (collectively referred to as the Ludlow Member east of Miles City, Montana) from the overlying Tongue River Member is the color differential between the lighter-colored upper portion and the somewhat darker lower portion (Brown, 1958). Although geologists working with subsurface data, principally geophysical logs, in the basin are trying to develop criteria for subsurface recognition of the LeboTullock and Tongue River-Lebo contacts, no definitive guidelines are known to have been published. Hence, for subsurface mapping purposes, the Fort Union Formation is not divided into its members for this study. During the Paleocene epoch, the Powder River Basin tropic to subtropic depositional environment included broad, inland flood basins with extensive swamps, marshes, freshwater lakes, and a sluggish but active northeastward discharging drainage system, superimposed on an emerging sea floor, near base level. Much of the vast area where organic debris collected was within a reducing depositional environment. Localized uplifts began to disturb the near sea level terrain of northeastern Wyoming following retreat of the Cretaceous seas. However, the extremely fine-grained characteristics of the Tongue River Member clastics suggest that areas of recurring uplift peripheral to the Powder River Basin were subdued during major coal deposit formation. 
The uplift of areas surrounding the Powder River Basin created a structural basin of asymmetric characteristic, with the steep west flank located on the eastern edge of the Big Horn Mountains. The axis of the Powder River Basin is difficult to specifically define, but is thought to be located in the western part of the Basin, and to display a north-south configuration some 15 to 20 miles ( 24 to $32 \mathrm{~km}$ ) east of Sheridan, wyoming. Thus, the sedimentary section described in this report lies on the east flank of the Powder River Basin, with gentle dips of two degrees or less disrupted by surface structure thought to relate to tectonic adjustment and differential compaction.

Some coal beds in the Powder River Basin exceed 200 feet $(61 \mathrm{~m})$ in thickness. Deposition of these thick, in-situ coal beds requires a discrete balance between subsidence of the earth's crust and in-filling by trememdous volumes of organic debris. These conditions in concert with a favorable ground water table, non-oxidizing clear water, and a climate amenable to the luxuriant growth of vegetation produce a stabilized swamp critical to the deposition of coal beds.

Deposition of the unusually thick coal beds of the Powder River Basin may be partially attributable to short-distance water transportation of organic detritus into areas of crustal subsidence. Variations in coal bed thickness throughout the basin relate to changes in the depositional environment. Drill hole data that indicate either the complete absence or extreme attenuation of a thick coal bed probably relate to location of the drill holes within the ancient stream channel system draining this low land area in Early Cenozoic time. Where thick coal beds thin rapidly from the depocenter of a favorable depositional environment, it is not unusual to encounter a synclinal structure over the maximum coal thickness due to the differential compaction between organic debris in the coal depocenter and fine-grained clastics in the 
adjacent areas.

The Wasatch Formation of Eocene age crops out over most of the central part of the Powder River Basin and exhibits a disconformable contact with the underlying Fort Union Formation. The contact has been placed at various horizons by different workers; however, for the purpose of this report, the contact is positioned near the top of the Roland coal bed as mapped by Olive (1957) in northwestern Campbell County, Wyoming, and is considered to disconformably descend in the stratigraphic column to the top of the Wyodak-Anderson coal bed (Roland coal bed of Taff, 1909) along the eastern boundary of the coal measures. No attempt is made to differentiate the Wasatch and Fort Union Formations on geophysical logs or in the subsurface mapping program that is a part of this CRO-CDP project.

Although Wasatch and Fort Union lithologies are too similar to allow differentiation in some areas, most of the thicker coal beds occur in the Fort Union section on the east flank of the Powder River Basin. Furthermore, orogenic movements peripheral to the basin apparently increased in magnitude during Wasatch time causing the deposition of friable, coarse-grained to gritty, arkosic sandstones, fine- to very fine-grained sandstones, siltstones, mudstones, claystones, brown-toblack carbonaceous shales, and coal beds. These sediments are noticeably to imperceptibly coarser than the underlying Fort Union clastics.

The Hylton Ranch Quadrangle is located in an area where surface rocks are classified into the Fort Union Formation and the Wasatch Formation.

Olive (1957) correlated coal beds in the Spotted Horse coal field with coal beds in the Sheridan coal field (Baker, 1929) and Gillette coal field (Dobbin and Barnett, 1927), Wyoming, and with coal beds 
in the Ashland coal field (Bass, 1932) in southeastern Montana. This report utilizes, where possible, the coal bed nomenclature used in previous reports. The Anderson coal bed was named by Baker (1929), and regional correlations by IntraSearch indicate the Anderson coal bed is correlative with the School coal bed. The School coal bed was named by previous workers.

\section{Data Sources}

Areal geology of the coal outcrops and associated clinker is derived from Smith and others (1972, Figure 7). The outcrop configuration is adjusted to the current topographic maps in the area.

The major sources of subsurface control, particularly on deep coal beds, is the geophysical logs from oil and gas test bores and producing wells. Some geophysical logs are not applicable to this study, for the logs relate only to the deep potentially productive oil and gas zones. More than eighty percent of the logs include resistivity, conductivity, and self-potential curves. Occasionally the logs include gamma, density, and sonic curves. These logs are available from several commercial sources.

All geophysical logs available in the quadrangle are scanned to select those with data applicable to Coal Resource Occurrence mapping. Paper copies of the logs are obtained, interpreted, and coal intervals annotated. Maximum accuracy of coal bed identification is accomplished where gamma, density, and resistivity curves are available. Coal bed tops and bottoms are picked on the logs at the midpoint between the minimum and maximum curve deflections. The correlation of coal beds within and between quadrangles is achieved utilizing a fence diagram to associate local correlations with regional coal occurrences. 
In some parts of the Powder River Basin, additional subsurface control is available from U. S. Geological Survey open-file reports that include geophysical and lithologic logs of shallow holes drilled specifically for coal exploration. Numerous subsurface data points are shown on Bureau of Mines Information Circular 8538, 1972, Figure 7, and where these data are utilized, the rock-coal intervals are shown on the coal Data Map (Plate 1). Inasmuch as these drill holes have no identifier headings, they are not set forth on the Coal Data Sheet (Plate 3). The geophysical logs of these drill holes were not available to IntraSearch to ascertain the accuracy of horizontal location, topographic elevation, and downhole data interpretation.

The reliability of correlations, set forth by IntraSearch in this report, vary depending on: the density and quality of lithologic and geophysical logs; the detail, thoroughness, and accuracy of published and unpublished surface geological maps, and interpretative proficiency. There is no intent on the part of Intrasearch to refute nomenclature established in the literature or used locally by workers in the area. Intrasearch's nomenclature focuses upon the suggestion of regional coal bed names applicable throughout the eastern Powder River Basin. It is expected and entirely reasonable that some differences of opinion regarding correlations, as suggestedby IntraSearch, exist. Additional drilling for coal, oil, gas, water, and uranium, coupled with expanded mapping of coal bed outcrops and associated clinkers will broaden the data base for coal bed correlations and allow continued improvement in the understanding of coal bed occurrences in the eastern Powder River Basin. 
The topographic map of the Hylton Ranch Quadrangle is published by the U. S. Geological Survey, compilation date, 1949. Land network and mineral ownership data are compiled from land plats available from the U. S. Bureau of Land Management in Cheyenne, Wyoming. This information is current to October 13, 1977.

\section{IV. $\quad$ Coal Bed Occurrence}

The Hylton Ranch Quadrangle is located south of the principal coal deposits of the Powder River Basin.

A suite of $81 / 2 \times 11 "(22 \times 28 \mathrm{~cm})$ maps is prepared for the Anderson (School) coal bed in all or parts of Section 17, 18, 19, 20, 29, and 30 in Township 35 North, Range 74 West, and all or parts of Sections 13, 24 and 25 Township 35 North, Range 75 West. The suite consists of a structure and overburden isopach map, and isopach and mining ratio map, an areal distribution of identified resources and identified resources map, and a coal development potential for surface mining methods map (Figures 1-4). The areal configuration of the coal bed outcrop is derived and enlarged from a 1:30,000 scale publication by Smith and others (1972). Numerous irregularities in outcrop elevations and the areal geologytopographic map relationship emphasize that this map presents a generalized configuration of the coal bed outcrop. The outcrop line joins an insufficient data line, a line generated by projecting the surface at the top of the Anderson (School) coal bed to intersection with the terrain. Horizontal accuracy of outcrop location is estimated at \pm 1000 feet $(305 \mathrm{~m})$.

No physical and chemical analyses are known to have been published regarding the Anderson (School) coal bed in the Hylton Ranch Quadrangle. However, an "as received" proximate analysis for the Anderson (School) coal bed north of the Hylton Ranch Quadrangle at the Dave Johnston mine, is as follows: 
COAL

BED

FIXED

NAME

CARBON \% MOISTURE \%

VOLATILES \% SULFUR \% BTU/LB

Anderson (School) * 9.68 29.48

26.41

34.43

0.52

7,830

(*) - Glass, G. B., 1975b,p. 165

The Coal Data Sheet, Plate 3, shows by columnar section, the interpretation of a geophysical well log. Inasmuch as no coal beds are identified in the well log, mean sea level is designated as datum.

The Anderson (School) coal bed ranges in thickness from less than 10 feet $(3 \mathrm{~m})$ in the eastern portion of the mapped area to more than 25 feet $(8 \mathrm{~m})$ in the western portion of the mapped area (Figure 1). Structure contours drawn on top of the Anderson (School) coal bed indicate a dip of two degrees or less to the northeast (Figure 2). The overburden above the Anderson (School)attains a maximum thickness of slightly over 200 feet $(60 \mathrm{~m})$ in the central portion of the mapped area (Figure 2).

V. Geological and Engineering Mapping Parameters

The correct horizontal location and elevation of drill holes utilized in subsurface mapping are critical to map accuracy. IntraSearch Inc., plots the horizontal location of the drill hole as described on the geophysical log heading. Occasionally this location is superimposed or near to a drillsite shown on the topographic map, and the topographic map horizontal location is utilized. If the ground elevation on the geophysical log does not agree with the topographic elevation of the drillsite, the geophysical log ground elevation is adjusted to conformance. If there is no indication of a drillsite on the topographic map, the "quarter, quarter, quarter" heading location is shifted within a small area until the ground elevation on the heading agrees with the topographic map elevation. If no elevation agreement can be reached, the well heading or data sheet is rechecked for footage 


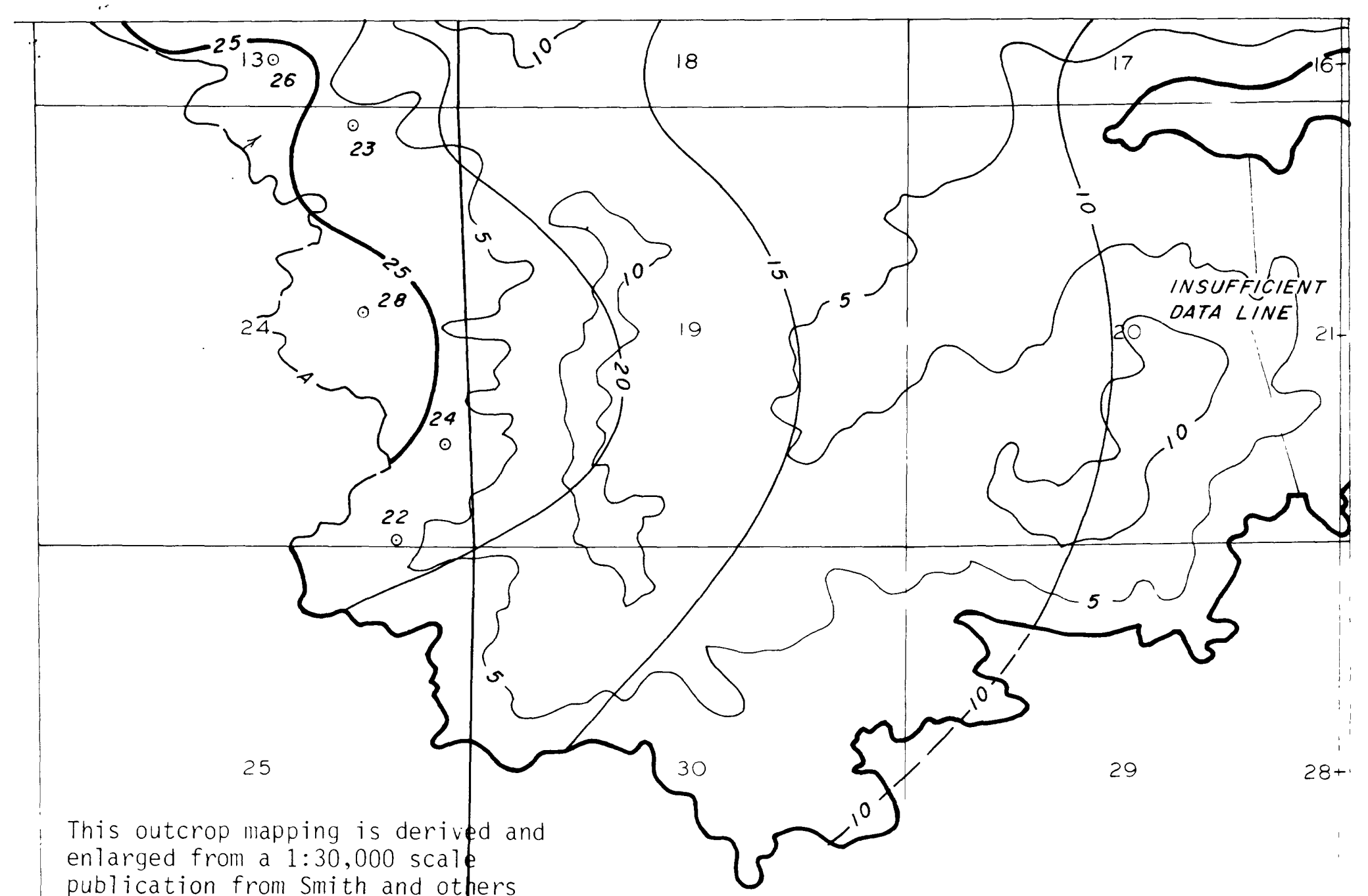
(1972, Fig. 7). Numerous irregularities in outcrop elevation $\$$ and the areal geology-topographic map

relationship emphasize that this map presents a generalized cohfiguration of the coal bed outcrop. Horizontal accuracy of outcrop location is estimated at +1000 feet $(305 \mathrm{~m})$. 
EXPLANATION FOR FIGURE 1

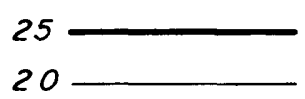

10

$\odot^{28}$

$\uparrow+---$
ISOPACHS OF COAL BED-Showing thickness in feet, interval 5 feet. Dashed where coal is burned or eroded.

MINING RATIO CONTOUR-Number indicates cubic yards of overburden per ton of recoverable coal by surface mining methods. Contours shown only in area suitable for surface mining within the stripping limit.

DRILL HOLE-Showing coal thickness in feet.

TRACE OF COAL BED OUTCROP-Showing coal thickness in feet, measured at triangle. Arrow points toward the coalbearing area. Coal bed dashed where inferred.

To convert feet to meters multiply feet by 0.3048 . 


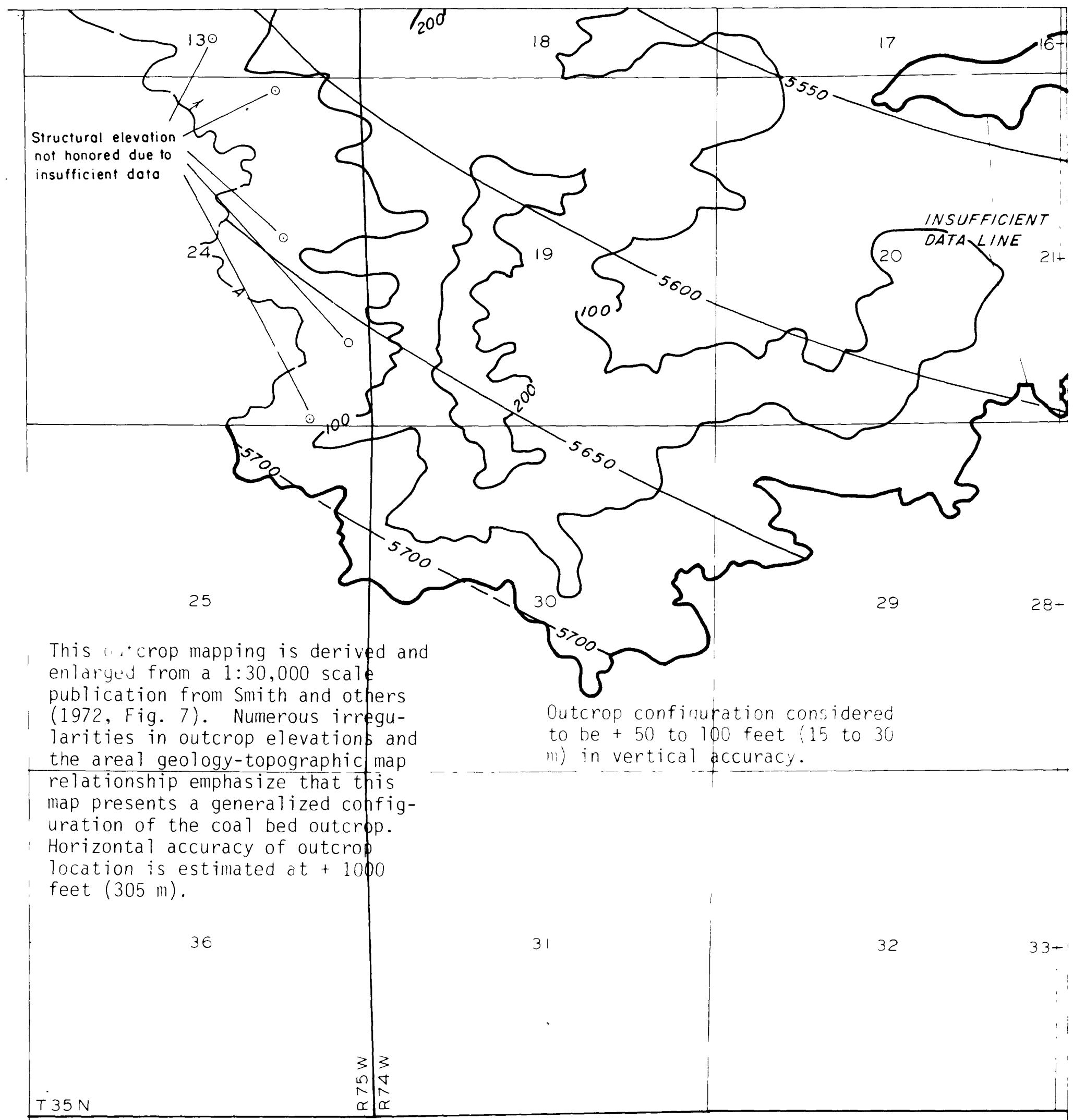

Base from U.S Geologicol Survey, 1949

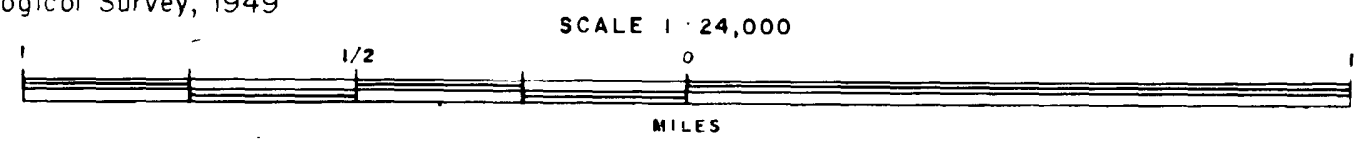

Complled in 1979

FIGURE 2

STRUCTURE CONTOUR AND ISOPACH OF OVERBURDEN MAP

OF ANDERSON COAL BED IN

HYLTON RANCH QUADRANGLE

CONVERSE COUNTY, WYOMMING

(see following page for Explanation) 
EXPLANATION FOR FIGURE 2

STRUCTURE CONTOURS-Drawn on top of coal bed. Contour interval 50 feet. Datum is mean sea level. Dashed where coal is burned or eroded.

OVERBURDEN ISOPACH-Showing thickness of overburden, in feet, from the surface to the top of the coal bed. Isopach interval 100 feet.

DRILL HOLE

$\odot$

TRACE OF COAL BED OUTCROP-Arrow points toward the coal-bearing area. Coal bed dashed where inferred.

To convert feet to meters multiply feet by 0.3048 . 

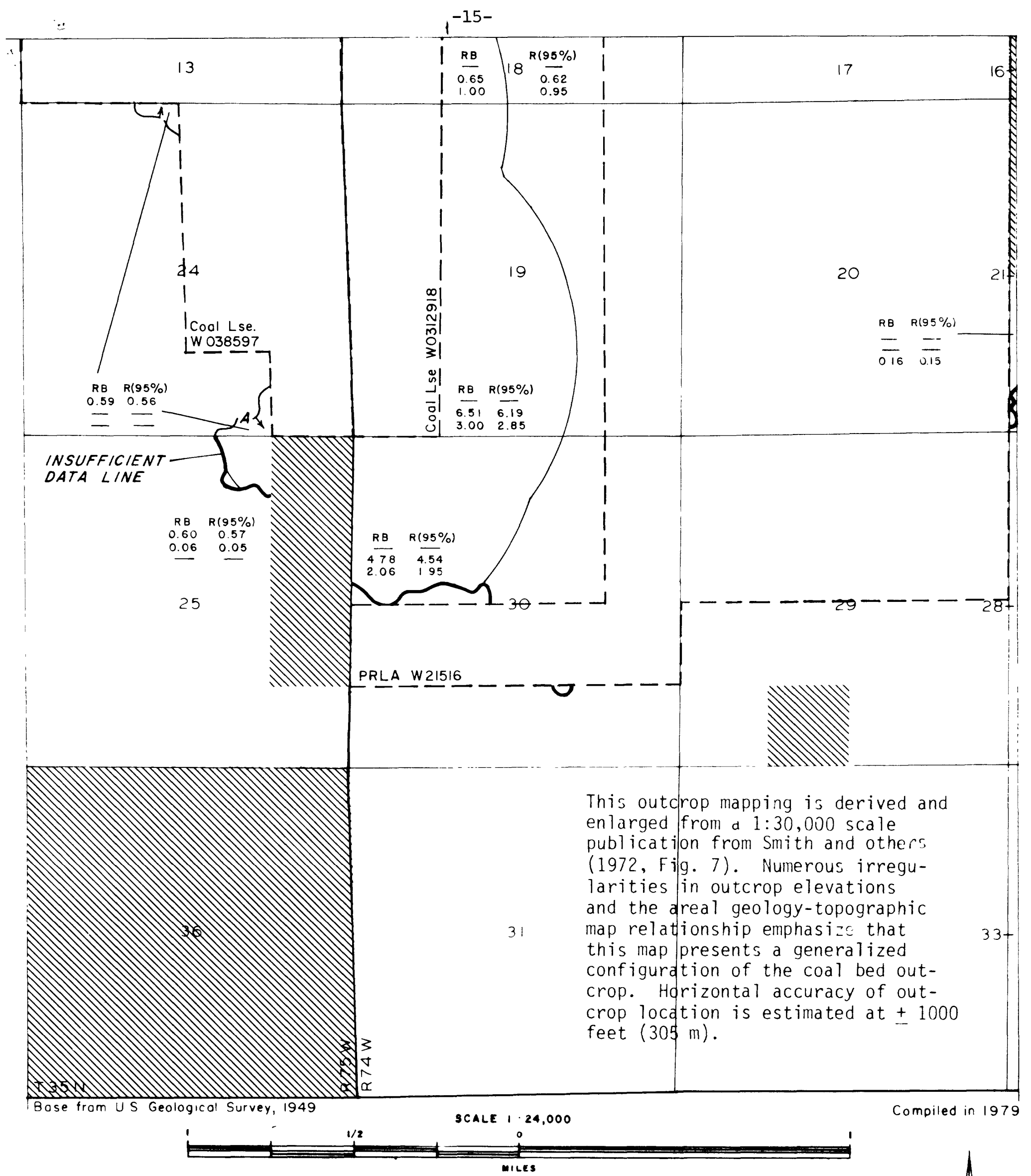

FIGURE 3

AREAL DISTRIBUTION OF IDENTIFIED RESOURCES

AND IDENTIFIED RESOURCES MAP

OF ANDERSON COAL BED IN

HYLTON RANCH QUADRANGLE

CONVERSE COUNTY, WYOMING

(See following page for Explanation)

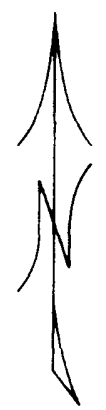


EXPLANATION FOR FIGURE 3

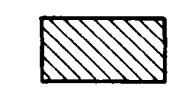

$\begin{aligned} & 1 \\ & L\end{aligned}--$

R8 $R(95 \%)$

- -

$651 \quad 619$

$3.00 \quad 2.85$
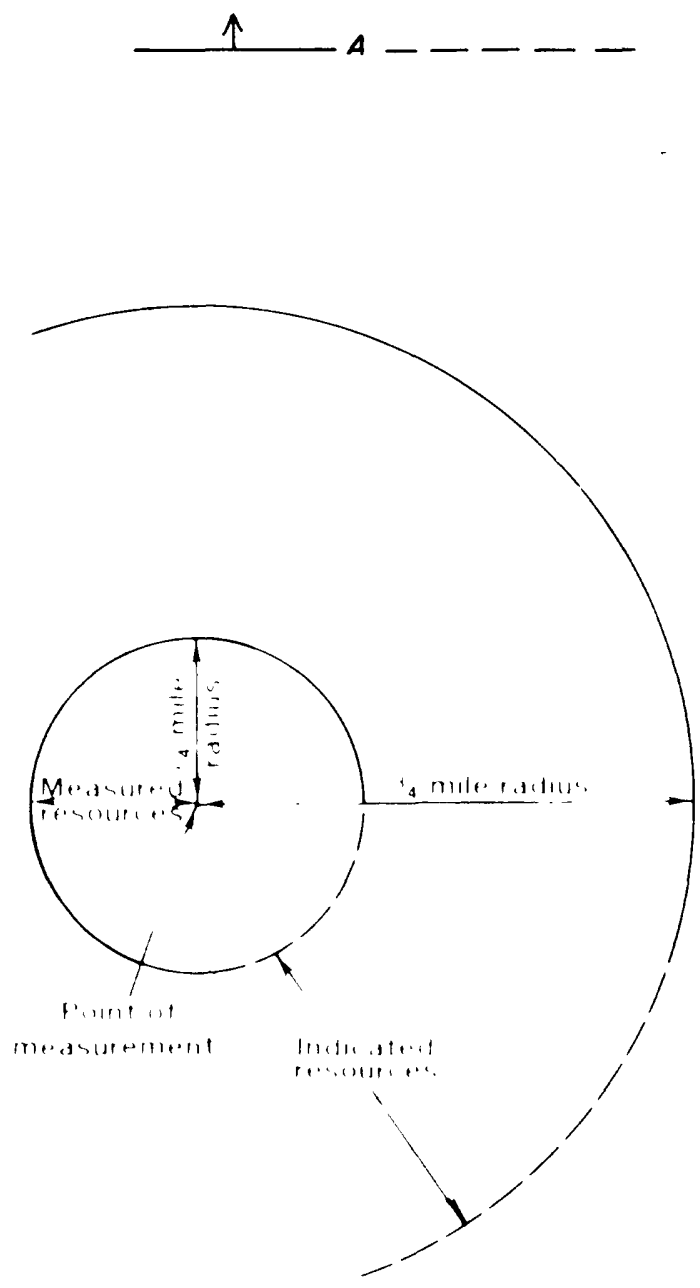

NON-FEDERAL COAL LAND-Coal tonnages not evaluated.

COAL LEASE-COAT LSe

PREFERENCE RIGHT LEASE APPLICATION-PRLA

IDENTIFIED RESOURCES OF COAL BED-In millioris of short tons. Dash indicates no resources in that category. Reserve Base (RB) $x$ the recovery factor $(95 \%)=$ Reserves $(R)$.

TRACE OF COAL BED OUTCROP-Arrow points toward the coal-bearing area. Coal bed dashed where inferred.

BOUNDARY LINES-Enclosing areas of measured, indicated and inferred coal resources of the coal bed. Dashed where projected from adjacent quadrangles. 


\section{$-17-$}

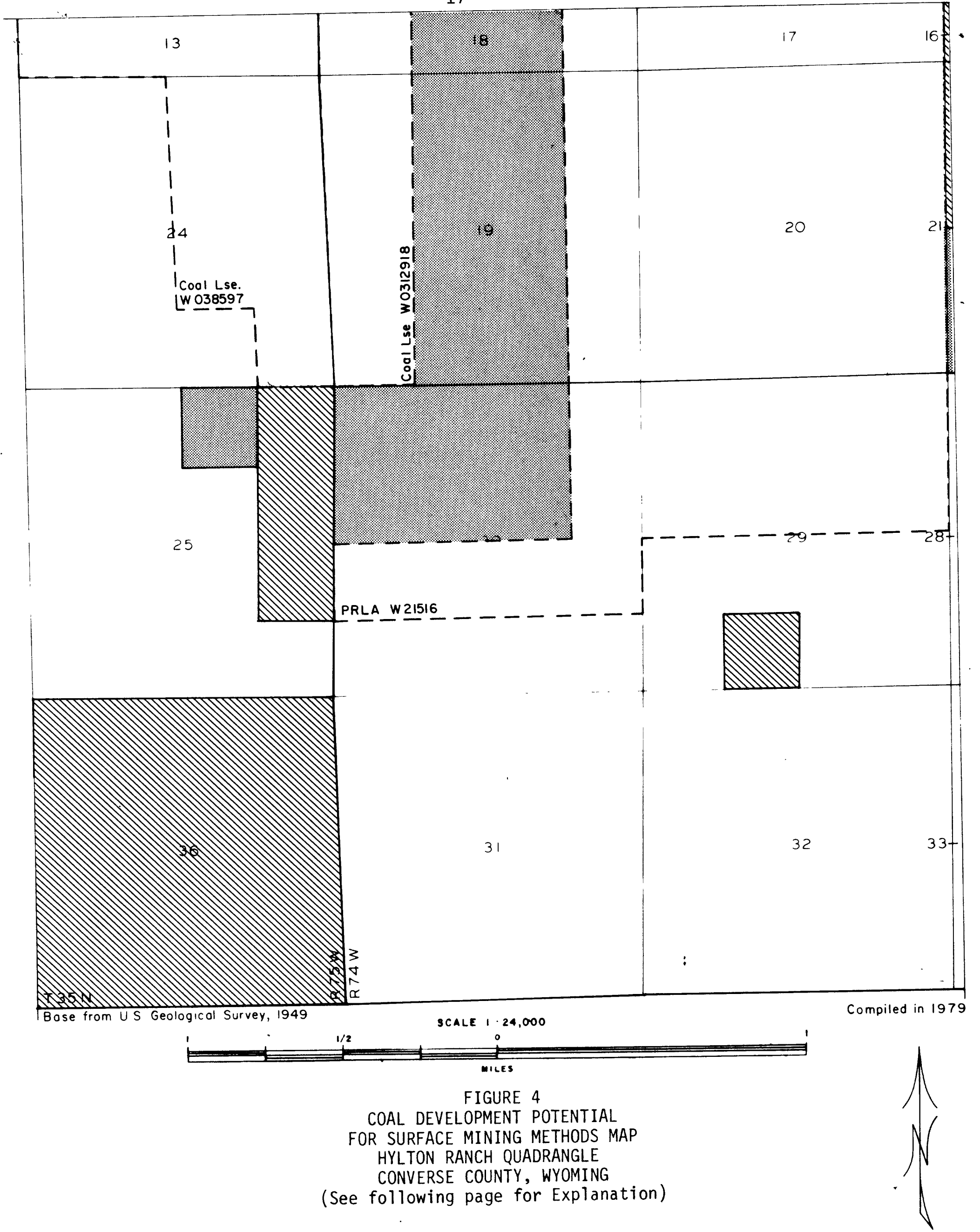




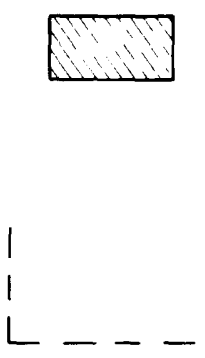

NON-?EDERAL COAL LAND-Coal development potential is not rated.

COAL LEASE-Coal Lse.

PREFERENCE RIGHT LEASE APPLICATION-PRLA

AREA OF HIGH COAL DEVELOPMENT POTENTIAL FOR SURFACE MINING METHODS-Area has mining ratio values ranging from 0 to 10 .

AREA OF UNKNOWI: COAL DEVELOPMENT POTENTIAL FOR SURFACE MINING METHODS-Area may tee underlain by coal, but where no data are available to determine a coal development potential. 
measurements and ground elevation accuracy. Inquiries to the companies who provided the oil and gas geophysical logs frequently reveal that corrections have been made in the original survey. If all horizontal location data sources have been checked and the information accepted as the best available data, the drillsite elevation on the geophysical log is modified to agree with the topographic map elevation. Intrasearch Inc., considers this agreement mandatory for the proper construction of most subsurface maps, but in particular, the overburden isopach, the mining ratio, and Coal Development Potential maps.

Subsurface mapping is based on geologic data within and adjacent to the Hylton Ranch Quadrangle area. Data from geophysical logs are used to correlate coal beds and control contour lines for the coal thickness, structure, and overburden maps. Isopach lines are also drawn to honor selected surface measured sections where there is sparse subsurface control. Where isopach contours do not honor surface measured sections, the surface thicknesses are thought to be attenuated by oxidation and/or erosion, hence not reflective of total coal thickness. Isopach lines extend to the coal bed outcrops, the projections of coal bed outcrops, and the contact between porcellanite (clinker) and unoxidized coal in place. Attenuation of total coal bed thickness is known to take place near these lines of definition; however, the overestimation of coal bed tonnages that results from this projection of total coal thickness is insignificant to the Coal Development Potential maps. Structure contour maps are constructed on the tops of the main coal beds. Where subsurface data are scarce, supplemental structural control points are selected from the topographic map along coal outcrops.

In preparing overburden isopach maps, no attempt is made to identify coal beds that occur in the overburden to a particular coal bed 
under study. Mining ratio maps for this quadrangle are constructed utilizing a ninety-five percent recovery factor. Contours of these maps identify the ratio of cubic yards of overburden to tons of recoverable coal. Where ratio control points are sparse, interpolated points are computed at the intersections of coal bed and overburden isopach contours using coal structure, coal isopach, and topographic control. On the Areal Distribution of Identified Resources Map (ADIR), coal bed reserves are not calculated where the coal is less than 5 feet $(1.5 \mathrm{~m})$ thick, where the coal occurs at a depth greater than 500 feet (152 m), where non-federal coal exists, or where federal coal leases, preferenceright lease applications, and coal prospecting permits exist.

Coal tonnage calculations involve the planimetering of areas of measured, indicated, inferred reserves and resources, and hypothetical resources to determine their areal extent in acres. An Insufficient Data line is drawn to delineate areas where surface and subsurface data are too sparse for CRO map construction. Various categories of resources are calculated in the unmapped areas by utilizing coal bed thicknesses mapped in the geologically controlled area adjacent to the insufficient data line. Acres are multiplied by the average coal bed thickness and 1750 , or 1770 (the number of tons of lignite $A$ or subbituminous C coal per acre-foot, respectively; 12,874 or 13,018 metric tons per hectare-meter, respectively), to determine total tons in place. Recoverable tonnage is calculated at ninety-five percent of the total tons in place. Where tonnages are computed for the CRO-CDP map series, resources and reserves are expressed in millions of tons. Frequently the planimetering of coal resources on a sectionized basis involves complexly curvilinear lines (coal bed outcrop and 500-foot stripping limit designations) in relationship with linear section boundaries and circular resource category boundaries. Where these relationships occur, 
generalizations of complexly curvilinear lines are discretely utilized, and resources and/or reserves are calculated within an estimated two to three percent plus or minus accuracy.

VI.

Coal Development Potential

Strippable Coal Development Potential. Areas where coal beds are 5 feet $(1.5 \mathrm{~m})$ or more in thickness and are overlain by 500 feet $(152 \mathrm{~m})$ or less of overburden are considered to have potential for surface mining and are assigned a high, moderate, or low development potential based on the mining ratio (cubic yards of overburden per ton of recoverable coal). The formula used to calculate mining ratios is as follows :

$$
M R=\frac{\text { to }(0.911) *}{t c(\operatorname{rf})} \quad \begin{aligned}
\text { where } & =\text { mining ratio } \\
\text { to } & =\text { thickness of overburden } \\
t c & =\text { thickness of coal } \\
r f & =\text { recovery factor } \\
0.911 * & =\text { conversion factor (cu. yds./ton) }
\end{aligned}
$$

$*_{A}$ conversion factor of 0.922 is used for lignite.

A surface mining potential map (Figure 4) is prepared utilizing the following mining ratio criteria for coal beds 5 to 40 feet ( 1.5 to $12 \mathrm{~m})$ thick:

1. Low development potential $=15: 1$ and greater ratio.

2. Moderate development potential $=10: 1$ to $15: 1$ ratio.

3. High development potential $=0$ to $10: 1$ ratio.

The following mining ratio criteria is utilized for coal beds greater than 40 feet $(12 \mathrm{~m})$ thick:

1. Low development potential $=7: 1$ and greater ratio.

2. Moderate development potential $=5: 1$ to $7: 1$ ratio.

3. High development potential $=0$ to $5: 1$ ratio.

The surface mining potential is high for approximately two percent of the Hylton Ranch Quadrangle. The area is located in the north-central part of the quadrangle. About forty-eight percent of the area is of unknown potential due to the paucity of surface control and depth of 
the no-record interval on the geophysical log. The remaining fifty percent of the area quadrangle is leased federal coal or non-federal coal. Table 1 sets forth the estimated strippable reserve base tonnages per coal bed for the quadrangle.

Underground Mining Coal Development Potential. No subsurface coal mining potential exists in the Hylton Ranch Quadrangle because no coal beds are known to be present at depths greater than 500 feet $(152 \mathrm{~m})$. In-Situ Gasification Coal Development Potential. The evaluation of subsurface coal deposits for in-situ gasification potential relates to the occurrence of coal beds more than 5 feet $(1.5 \mathrm{~m})$ thick buried from 500 to 3000 feet $(152$ to $914 \mathrm{~m}$ ) beneath the surface. This categorization is as follows:

1. Low development potential relates to: 1) a total coal section less than 100 feet $(30 \mathrm{~m})$ thick that lies 500 feet $(152 \mathrm{~m})$ to 3000 feet $(914 \mathrm{~m})$ beneath the surface, or 2) a single coal bed or coal zone 5 feet $(1.5 \mathrm{~m})$ or more in thickness which lies 500 feet $(152 \mathrm{~m})$ to 1000 feet $(305 \mathrm{~m})$ beneath the surface.

2. Moderate development potential is assigned to a total coal section from 100 to 200 feet (30 to $61 \mathrm{~m}$ ) thick, and buried from 1000 to 3000 feet (305 to $914 \mathrm{~m}$ ) beneath the surface. 3. High development potential involves 200 feet $(61 \mathrm{~m})$ or more of total coal thickness buried from 1000 to 3000 feet (305 to $914 \mathrm{~m}$ ).

Inasmuch as no coal beds are known to be present at depths greater than 500 feet $(152 \mathrm{~m})$, the coal development potential for insitu gasification within the Hylton Ranch Quadrangle is non-existent, hence no $C D P$ map is generated for this map series. 


\section{SELECTED REFERENCES}

Baker, A. A., 1929, The northward extension of the Sheridan coal field, Big Horn and Rosebud Counties, Montana: U. S. Geol. Survey Bull. $806-\mathrm{B}, \mathrm{p} .15-67$

Bass, N. W., 1932, The Ashland coal field, Rosebud, Powder River, and Custer Counties, Montana: U. S. Geol. Survey Bull. 831-B, p. 19-105.

Brown, R. W., 1958, Fort Union Formation in the Powder River Basin, Wyoming: Wyo. Geol. Assoc. Guidebook, Thirteenth Annual Field Conf., p. 111-113.

Denson, N. M., Dover, J. H., and Osmonson, L. M., 1978, Structure contour and isopach maps of the Wyodak-Anderson coal bed in the Reno JunctionAntelope Creek area, Campbel1 and Converse Counties, Wyoming: U.S. Geol. Survey Misc. Field Investigation MF-961, scale 1:125,000.

Dobbin, C. E., and Barnett, V. H., 1927, The Gillette coal field, northeastern Wyoming: U.S. Geo1. Survey Bull. 796-A, p. 1-50.

Glass, G. B., 1975a, Review of Wyoming coal field, 1975; Wyoming Geol. Survey Public Information circ. 4, p. 10. - 1975b, Analyses and measured sections of 54 wyoming coal samples (collected in 1974): Wyoming Geological Survey Report of Investigations No. 11, p. 156-167.

Jacob, A. F., 1973, Depositional environments of Paleocene Tongue River Formation: Am. Assoc. of Petroleum Geologists Bull, vol. 56, no. 6, p. 1038-1052. McKay, E. J., 1974, Preliminary geologic map of the Bertha 2 NW (Rocky Butte) Quadrangle, Campbell County, Wyoming: U. S. Geol. Survey Open-File Report 74-173, scale 1:24,000. 


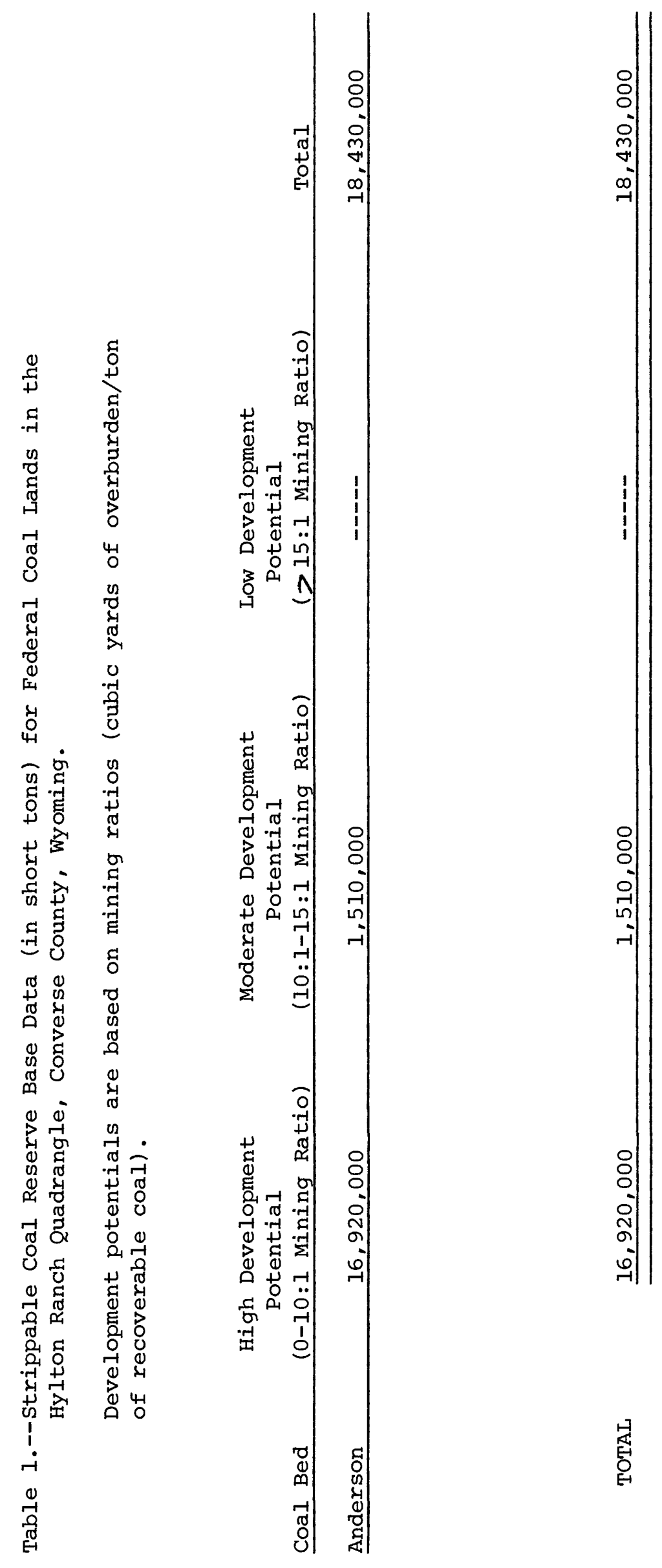


Olive, W. W., 1957, The Spotted Horse coal field, Sheridan and Campbell Counties, Wyoming: U. S. Geol. Survey Bull. 1050, 83 p.

Schell, E. M., and Mowat, G. D., 1972, Reconnaissance map showing some coal and clinker beds in the Fort Union and Wasatch Formations in the eastern Powder River Basin, Campbell and Converse Counties, Wyoming: U. S. Geol. Survey Open-File Report, scale 1:63,360.

Sharp, W. N., and Gibbons, A. B., 1964, Geology and uranium deposits of the southern part of the Powder River Basin, Wyoming: U. S. Geol. Survey Bull. 1147-D, $60 \mathrm{p}$.

Smith, J. B., Ayler, M. F., Knox C. C., and Pollard, B. C., 1972, Strippable coal reserves of Wyoming; location, tonnage and characteristics of coal and overburden: U. S. Bureau of Mines Information Circular 8538, 51 p. Taff, J. A., 1909, The Sheridan coal field, Wyoming: U. S. Geol. Survey Bull. $341-$, p. 123-150.

Warren, W. C., 1959, Reconnaissance geology of the Birney-Broadus coal field, Rosebud and Powder River Counties, Montana: U. S. Geol. Survey Bull. 1072-J, p. 561-585.

Weimer, R. J., 1977, Stratigraphy and tectonics of western coals, in Geology of Rocky Mountain Coal, A Symposium, 1976: Colorado Geol. Survey Resource Series 1, p. 9-27. 